\title{
Fear of Violence and Criminality in the Region of Gjilan, Kosovo
}

\author{
Ahmet Maloku \\ University College "Gjilani", Lecturer \\ maloku.ahmet@gmail.com
}

Doi:10.5901/mjss.2015.v6n2s5p29

\begin{abstract}
It has already passed a long time since the second half of the XX ( twentieth) century, fear of crime has been subjeced to an intensive study of many criminologist. Even today it is difficult to define precisely this notion because we are dealing with something that falls in the domain of subjective perception. Today the fear of violence and crime is considered as a problem, which mostly affects the quality of life not only of individuals but also the wider circle we live in. Many criminologist consider that fear of crime as a bigger problem than the official rate of offenses recorded in modern urban centers. The purpose of this research is to get to know the imensity of this problem compared to official figures, and how some of important factors affect sensivity of Gjialn citizens security in the sense of security of citizens in Gjilan, Kosovo.
\end{abstract}

Keywords: Fear of crime, violence, victimization, prevention of crime.

\section{Introduction}

Criminality is a negative social phenomenon, which has been accompanying every society throughout all stages of its development. Most European criminologists believe that fear of crime is a bigger problem than the official rate of recorded offenses in modern urban centers. Crime and fear of crime reduce the quality of life of many Gjilan citizens, especially to elderly, children and minors, those living in the poorest areas with a higher density of population.

Fear of crime can be defined as the experience of an individual or a group that represents trust, perception or emotion in relation to crime and public order, and has a negative effect on human's feelings, thoughts or behavior and quality of life (Gjoni, 2006). In other words, we are dealing with emotional reaction and unpleasant cases in relation with criminals.

Fear of crime is mainly and primarily psychological, but perceived risk of victimization includes cognitive evaluation of probability that in reality happens as victimization (Warr, 2000).

Recent years we have witnessed many events in the field of crime throughout Kosovo, witnessing various criminal acts, seeing and hearing through electronic and print media.

At the same time, according to the annual work report of the Kosovo Police official and police statistics is shown that the total number of offenses in the Republic of Kosovo in 2014 was 36,514, compared with the statistical data of 2014 and those of 2013, the number of offenses was 36642. This indicates that the number of cases and offenses have declined up to 4. 89\%, respectively 00:35\%. Based on an investigation, cases have increased from 2. 99 in 2014 and from $66.8 \%$ in 2013 , to $69.79 \%$ (MIA, 2014). In 2013 the number of offenses has increased by $2.97 \%$ compared to those of 2012 were 35585. Comparing discovered cases of the years 2012/2013 in percentage, is clear that since 2013 discovery of cases has increased up to 2. 01\% ( MIA, 2013). In the Gjilan Regional Directorate the number of criminal cases in 2014 is the participation of 9\% or 3286 criminal cases in total offenses at the national level of 36,514.

Despite the successful police organized at central and local levels, it has been seen a reduction of offenses committed in the past, but the factors that affect the fear of violence and crime in Gjilan region are manifold and complex, where are included socio-demographic characteristics, the earlier victimization, exposure to certain topics in the media, use of personal protective measures, previous contacts with the police and judicial bodies, the perception of neighbors and personal traits, etc.

Most European criminologists believe that the fear of violence and crime is a bigger problem than the official figures of offenses recorded. This situation is quite logical, because, we in Kosovo for years have been hearing official reports on crime which situation is almost a "satisfactory" chronic.

The population of Gjilan still perceives criminality as one of the greatest concerns of this time. In this context, this research is an attempt to provide answers to the question, to what extention is the fear of violence and crime in Gjilan 
region.

\section{Subject of Research}

Phenomenological analysis needs, we have undertaken an empirical research which includes structure, social psychological, social - demographic fear of crime - a sense of danger which as such constitutes the subject matter of this research in the town of Gjilan.

Criminality is being fought by all means, and by various national strategies in cooperation with all relevant institutions responsible for it. Nevertheless it is very flexible and is changing the form of action by leaving bad "effects" in the region where it operates. On the other side it lowers sconfidence of institutions which are responsible to fight crime. Therefore, the content of this research is measured by different indicators due to fear of crime.

\subsection{The goal of research}

The purpose of empirical research plan is trying an objectivity of the security situation in Gjinal town, using some new methods of the criminality accuracy. Volume, dynamics and structure of criminality in any society can be assessed by various methods. Official statistics provide us with data on the number of persons the police dealing with, courts and institutions for enforcement of criminal sanctions. The success of these institutions depends to what extenssion they have managed to lower the citizens fear from crime. If citizens are disappointed by these authorities which are just some factors to measure crime, the fear would be greater towards criminality. Therefore, the main goal of this research would be collecting data of fear in terms of violence and criminality by various factors that influence and determine the perception of citizens in terms of violence and crime in the town of Gjilan.

\subsection{Research method}

Methodological opus means two methods. In fact, it comes to methods of analyzing the meta-analytic literature and examples of good practice in the introduction section, the theoretical part of the paper, with proper use and the method of content analysis and case studies. In the context of empirical work on which we have been exploring the sense of security of the citizens of Gjilan and compare that feeling on the quality and quantity of official indicators of criminality from the records of formal control bodies. As a tool in this research, we have used the questionnaire survey (for poll violence, $N=270$ respondents), arranged in the correct way, with questions formulated previously defined and providing the answers. The survey in this research was the oral survey, where the interviewer ask questions orally based on survey instruments and has recorded responses to the questionnaire.

In this research, we have used individual and anonymous survey which is simultaneous and the most successful and frequent surveys. Knowing the importance of its plot - mass phenomena, the connection with general scientific statistical method, its characteristics: the systematization is provided through a responsible work in the conceptualization and design of research by our staff, the relative duration and economizing. In this process carefully pronounced operationalization facility is dedicated to research, hypothesis, indicators, questionnaires, sampling and training of enumerators.

\subsection{Working methodology}

\subsubsection{Instrument}

In this survey was used questionnaire of Wurffov for fear of criminality which is used in many international researches. (Van der Wurff, A. , Van Staalduinen, L. , Stringer, P. 1989), the used questionnaire consists of several variables summarized in groups:

1. Socio-demographic general characteristics (residence, age, gender and victimization of an offense, the timeperiod of residence in the last address, residential status, educational level, position in the labor market.)

2. Self perception of the respondents and their behavior. (Calculation of the running speed, the ability of financial survival, self-assessment of health status, frequency of association with people, attending the neighborhood association, attending the visit friends in the neighborhood, risk assessment in certain countries). Fear of violence and crime in Gjilani region is explored through the scale from 1 (impossible, slow, weak, never) to the 5 level (very easy, fast, very well, very often) in which participants have to assess self-perception and behavior 
among these levels in reply to the posed questions.

3. Eight characteristics of socio-psychological model of fear of crime (I think the most evil men threaten me and my property, I think people are jealous of me, think I'm able to control a potential attacker, usually you deviate problems, generally trusting strangers, I do not believe to some people in my area. There are times when getting back home I thing I might get attecked by somebody, but still I have a faith that the path I have chosen to go back home is safe).

4. Six situations in terms of security feeling or insecurity in relation to criminality is closely connected with four socio-psychological componenets: atractivity, misfaith, power and space criminality.

\subsection{The sample of respondents}

Sampling, selection of the method to carry out a survey is a complex process in which scientists, experts, supervisor and interviewers participate to choose a certain number of units representative of the knowledge and the completion of the phenomena on the basis of those units. The sample of respondents in this research consists of Gjilan residents aged over 18 years old selected by random method with previously trained interviewers. The starting point of the interviewers and the definition of the way in which they move is not made casually, it has its own importance in the sampling system. The starting point has fulfilled the spatial dimensions of stratification that has surrounded our "area of responsibility«. Selecting family has been a very difficult task in the process of stratification to define in which families survey would be realized.

\subsection{Hypothetical framework}

The whole instrumental package, the anticipated contents even the purpose, subject and methodological framework is possible, testing through a general hypothesis records: "Official statistics of crime in Gjilan, in quantitative terms, is distinguished from the perception of crime by the citizens of this city gained from their victimology research properties ".

\section{Summary of Survey Conducted in the Gjilan City}

The perception of fear of violence and crime in the region of Gjilan, within the research surveyed individuals according to the structure specified below. During the survey interlocutors were informed with the subject of research, and the same individuals voluntarily participated in it. Research based on individual statement in the town of Gjilan on fear from criminality and its danger was conducted with a sample of 270 respondents, aged over 18 years.

Through research on gender variables it comes out the best predictor of fear from crime. This link has been proven by many researchers (Garofalo, 1979; Tolle, 2001; Skogan \& Maxfield, 1981; Ferraro \& LaGrange, 1987; Rountree \& Land, 1996; Borooah \& Carcach, 1997; Lane \& Meeker, 2000) with results that women have a higher degree of fear than males, while according to research (Fettah of Sacco, 1989) older females were less likely to be victims. These thoughts also match our records where research results have shown us that women feel more fear of crime than men.

Employees are more afraid of crime than the unemployed ones, those who have been victims of crime feel less dose of fear than those who were not. We also have the case of unemployed persons who in this research is shown to have more fear than they used to have it before.

Many scientists have been dealing with the fear of crime research, and studies have confirmed its existence in different populations (Chockalingam \& Srinivasan, 2009; Dolezal, 2009; Gjoni, 2006). In the meantime research defined a large number of determinants of fear of crime, including socio-demographics various features, such as gender, age and rural origin - urban. 
Table 1. Structure of respondents after socio-demographic model of fear of crime.

Descriptive Statistics

\begin{tabular}{|c|c|c|c|c|c|}
\hline & $\mathrm{N}$ & Minimum & Maximum & Mean & Std. Deviation \\
\hline Running speed: "In relation to average people" running & 270 & 1 & 5 & 3.54 & 1.155 \\
\hline How do you evaluate your health this year? & 270 & 1 & 5 & 4.07 & 1.174 \\
\hline Are you able to collect 250 Euro "in a cuiqk run"without a loan from a bank? & 270 & 1 & 5 & 2.72 & 1.433 \\
\hline I get on well with pople & 270 & 1 & 5 & 3.82 & 1.117 \\
\hline How often do talk with your nbeighbours? & 270 & 1 & 5 & 3.85 & 1.074 \\
\hline Do you visit your neighbours? & 270 & 1 & 5 & 3.56 & 1.211 \\
\hline How often do you walk alone at night? & 270 & 1 & 5 & 2.93 & 1.391 \\
\hline Valid N (listwise) & 270 & & & & \\
\hline
\end{tabular}

Regarding the age group of respondents appears that each $1 / 4$ is betweeen 18 to 35 years old. If we focus ourselves at the responses from the socio-demographic data, it comes out that the speed (average 3.54) of running and health (average of 4.07) is a good rate compared to the ability "in a quick run" to collect 250 euros without loan from the bank with an average scale of 2.72. Analyzing the two important indicators of high unemployment among respondents with a percentage of $30.37 \%$ or the other indicator of young age, $62 \%$ of respondents there is a good average in general.

Regarding association with people, talking to people in the neighborhood, and visiting friends who live in the neighborhood, there is an average that is closed to 4 (scale one 1 never, whereas scale 5 often), respectively association with people 3.82, conversation with neighbors 3.85, and visiting friends who live in the neighborhood with 3.56 .

Research carried out in Europe (European Communities, 2004), the US (Gallup, 2009), India and Japan (Chockalingam \& Srinivasan, 2009) show a lower representation of fear of crime in general population. In a study conducted in 36 countries across Europe, USA, Canada, Australia and New Zealand, which was held in 1989, 1992, 1996 and 2000 and in which the total sample consisted of 162,346 people, participants answered an average of feeling quite safe when walking alone at night in the city, and the level of fear was approximately the same in all European countries and it has not changed significantly over time (European Communities, 2004). The situation is similar in the US, where in 2009 Gallup poll, $66 \%$ of respondents state that they feel themselves safe when moving through the city during night.

From other socio demographic data we see that the walk at night by citizens is expressed with an average sample of respondents $N=270$ of 2.93. the range of 1 to 5 . Namly, citizens of the region of Gjilan do not feel very safe while walking at night. They lack safety and it cannot be compared with other world cities.

The respondents see as a huge problem groups of young-bands where they felt very concerned at a frequency of 180 , or with a large proportion of $67.70 \%$.

Table 2. Youth gangs (groups)

\begin{tabular}{|cc|c|c|c|c|}
\hline & Frequency & Percent & Valid Percent & Cumulative Percent \\
\hline Valid & A very big problem & 180 & 66.7 & 66.7 & 66.7 \\
& A big problem & 55 & 20.4 & 20.4 & 87.0 \\
& A small problem & 25 & 9.3 & 9.3 & 96.3 \\
It is not a problem & 10 & 3.7 & 3.7 & 100.0 \\
Total & 270 & 100.0 & 100.0 & \\
\hline
\end{tabular}

If we take a retroactive look to the last year, police statistics shows that the security situation in Gjilan is not so enviably, since it has been based on the earlier problems of youngsters- groups who are split into two and they have with them large numbers of their members, which is a major problem and concern for all authorities dealing with social control. These authorities have been creating great strategy to combat this phenomenon and to prevent it it in the future.

Nearly half of respondents, respectively, $47.40 \%$ or with frequence of 128 from $N=270$ felt confident in their district compared to $1 / 7$ or $14.80 \%$ of those who felt threatened. 
Table 3. Structure of respondents to the sense of security at night in their district

\begin{tabular}{|lc|c|c|c|c|}
\hline & & Frequency & Percent & Valid Percent & Cumulative Percent \\
\hline Valid & Very safe & 49 & 18.1 & 18.1 & 18.1 \\
& Quite safe & 53 & 19.6 & 19.6 & 37.8 \\
& Safe & 128 & 47.4 & 47.4 & 85.2 \\
& Risked & 40 & 14.8 & 14.8 & 100.0 \\
& Total & 270 & 100.0 & 100.0 & \\
\hline
\end{tabular}

With an average of 1.68 , or $57 \%$ of respondents who are ranked in the first degree (1-5) and who feel very concerned with the risk of theft. Their main fear 6 indicators presented in question 3 is theft, a problem for them is very disturbing.

Table 4. Riskiness feeling of theft

\begin{tabular}{|cc|c|c|c|c|}
\hline & Frequency & Percent & Valid Percent & Cumulative Percent \\
\hline Valid & Quite big koncern & 154 & 57.0 & 57.0 & 57.0 \\
& Relative koncern & 69 & 25.6 & 25.6 & 82.6 \\
& Average koncern & 31 & 11.5 & 11.5 & 94.1 \\
Small koncern & 12 & 4.4 & 4.4 & 98.5 \\
No concern at all & 4 & 1.5 & 1.5 & 100.0 \\
Total & 270 & 100.0 & 100.0 & \\
\hline
\end{tabular}

But if you look at the statistics of the annual report of 2014 the number of thefts has declined by $10.83 \%$ or theft offenses 7748 compared with 2013 by 8689 offenses of theft. This factor alone does not reduce the fear of crime from theft. It is known that this fear is dependent on many different factors. After feeling the danger of theft, respondents feel afraid of the danger or fraud and feel very concerned with the frequency of 134 from $\mathrm{N}=270$ or $49.60 \%$

Table 5. Riskiness feeling of fraud

\begin{tabular}{|lc|c|c|c|c|}
\hline & Frequency & Percent & Valid Percent & Cumulative Percent \\
\hline Valid & Quite big koncern & 134 & 49.6 & 49.6 & 49.6 \\
& Relative koncern & 59 & 21.9 & 21.9 & 71.5 \\
& Average koncern & 46 & 17.0 & 17.0 & 88.5 \\
Small koncern & 26 & 9.6 & 9.6 & 98.1 \\
No conceren at all & 5 & 1.9 & 1.9 & 100.0 \\
Total & 270 & 100.0 & 100.0 & \\
\hline
\end{tabular}

Our respondents to the following question "Is there a part of the city where you would never go alone at night?" $66.70 \%$ answered that there is no part of the city where they would not go at night, which is a fair indicator for a good feeling of security in Gjilan. The rest of the respondents answered that there were still places, neighborhoods where there would not attend lonely at night is $33.33 \%$.

Table 6. Are there parts of the city where they would not go alone at night?

\begin{tabular}{|c|c|c|c|c|c|}
\hline & & Frequency & Percent & Valid Percent & Cumulative Percent \\
\hline \multirow[t]{6}{*}{ Valid } & No & 180 & 66.7 & 66.7 & 66.7 \\
\hline & 7 Korriku & 35 & 13.0 & 13.0 & 79.6 \\
\hline & Arbëria & 21 & 7.8 & 7.8 & 87.4 \\
\hline & Baleci & 13 & 4.8 & 4.8 & 92.2 \\
\hline & Dardania & 1 & .4 & .4 & 92.6 \\
\hline & Dheu i Bardhë & 4 & 1.5 & 1.5 & 94.1 \\
\hline
\end{tabular}




\begin{tabular}{|c|c|c|c|c|}
\hline Kodra e Dëshmorëve & 1 & .4 & .4 & 94.4 \\
Grave yard & 1 & .4 & .4 & 94.8 \\
Sports Hall Yard & 6 & 2.2 & 2.2 & 97.0 \\
Hospital Yard & 1 & .4 & .4 & 97.4 \\
Parks & 3 & 1.1 & 1.1 & 98.5 \\
City Suburb & 2 & .7 & .7 & 99.3 \\
Zabeli & 2 & .7 & .7 & 100.0 \\
Total & 270 & 100.0 & 100.0 & \\
\hline
\end{tabular}

They claim that the most dangerous area remains the street "7 Korriku" with $12.96 \%$, or with a frequence of 35 and then Arbëria neighborhood comes with a frequency of 21 or $7.78 \%$. and in third place is the neighborhood of Baleci with $4.81 \%$ or with a frequency of 13 . But the remaining percentages are very small that will appear in contuinity of this project.

$9.60 \%$ of our respondents have replied that their propertiy damages would be compensated in case of any possible damage caused by somebody, it is concretely with $2.20 \%$, or with a frequence of 6 of those who have secured property with insurance companies with $7.40 \%$ or with a frequence of 20 who have secured their property at a private insurance company.

Table 7. Structure of respondents on the manner of choosing insurance in order to offset any damage caused by possible refraction.

\begin{tabular}{|cc|c|c|c|c|}
\hline & & Frequency & Percent & Valid Percent & Cumulative Percent \\
\hline Valid & No & 244 & 90.4 & 90.4 & 90.4 \\
& Insurance company & 6 & 2.2 & 2.2 & 92.6 \\
& Private Security & 20 & 7.4 & 7.4 & 100.0 \\
& Total & 270 & 100.0 & 100.0 & \\
\hline
\end{tabular}

Each of the 15th respondents has been a victim of any offense. The risk is theft at a scale of $11.11 \%$, then it is victimization by being fraud at a level of 3.70 .

Respondents to undertake various security measures on the fear of crime, respectively feelings of danger from crime have always taken steps to avoid contacts with unknown people at night (with an average of 1.71); often (with an average of 2.17). People usually take measures to avoid certain roads, streets or parks. But (with an average of 3.22) Night respondents sometimes use taxis, etc. Respondents also sometimes (with an average of 3.69) take security measures to keep safe large amounts of money.

Undertaking security measures while getting out from the apartmen is very necessary, and it has to be followed by strict security measures (with a scale of 2.87). To the extent that rarely take as a measure providing hedge funds holding himself responded (with an average of $4.43 \%$ ) of respondents from Gjilan. Perceived threats to dangerous places among the respondents from the sample $\mathrm{N}=270$ are in the first place (streets, shops, parks, recreational places) with $66.30 \%$, then the second row of hazards in their view are ranked recreation sites $48.15 \%$, whereas in the first place of not being at risk are shops, sample $=270$ with $91.85 \%$.

Table 8. Structure of respondents after socio-psychological model of fear of crime

\begin{tabular}{|c|c|c|c|c|c|}
\hline \multicolumn{6}{|l|}{ Descriptive Statistics } \\
\hline & $\mathrm{N}$ & Minimum & Maximum & Mean & Std. Deviation \\
\hline I think, evil pepole put me in risk and my wealth & 270 & 1 & 5 & 3.33 & 1.435 \\
\hline I think people are jealous to me & 270 & 1 & 5 & 2.73 & 1.359 \\
\hline I think I am enough capable to fight any potential attacker & 270 & 1 & 5 & 3.14 & 1.337 \\
\hline Mainly I avoid problems & 270 & 1 & 5 & 4.46 & 1.152 \\
\hline I talk to unknown people in general & 270 & 1 & 5 & 2.01 & 1.354 \\
\hline I do not have faith to some people in my area & 270 & 1 & 5 & 2.93 & 1.410 \\
\hline On the way back home I have a feeling someone might attack me & 270 & 1 & 5 & 2.87 & 1.458 \\
\hline $\begin{array}{l}\text { Leaving home, I am pretty sure that the way to my destination is secured. } \\
\text { Valid N (listwise) }\end{array}$ & $\begin{array}{l}270 \\
270\end{array}$ & 1 & 5 & 3.27 & 1.367 \\
\hline
\end{tabular}


The socio-psychological model of fear of crime, the questions have different answers from the respondents but not having an extreme departure from the scale 1 (strongly disagree) to 5 scale (completely agree) but a concentration between scale 2 and 3. More specifically, at the question "I think the most evil men threaten me and my wealth" there is an average scale of $3.33 \%$, while the question "I think people are jealous of me" has an average rate of $2.73 \%$. Whereas the prevalence of potential attackers is of an average of 3.14 Just to avoid the problems there is a grown average that leads towards level 5 (completely agree) with 4.46. Faith to strangers is at the lowest level of socio-pathological model with an average of 2.13 .

As far as the risk sentiment as to how much endangered would you feel in the evening when you're alone, you do not welcome visitors, someone knocks on your door, the respondents answered with a rate of 2.86 (from an average of 15) this respond relatively is endangered. But enough threatened feel our respondents finding themselves in a cafe in a Serbian village in the municiplaity of Gjilan where no telephone access is. In thi scase the respondents answered with an average of 1.94. Here the respondents answered with a lower average to all questions to the sense of danger.

As mentioned above, the factors influencing the fear of crime - a sense of danger in Gjilan, are multiple and complex and one of them is the exposure of certain topics in the media. The media largely contribute to the formation of attitude about crime and its presence in society. Graber (1980) showed that $95 \%$ of people rely on the media as the main source of information on criminality. Therefore, fear of crime can be linked to media exposure to crime. Selection of real events and its nonrealistic dramatization distort public perception problem. Doob and MacDonald (1979) have assumed that frequent exposure on television will promote fear of crime, it is not because of greater exposure to television, but for the reason that people who watch television more often tend to live in areas in which objectively happen more criminality.

In this regard when asked respondents "how much information affects the electronic and print media in your sense of security" sometimes there is an answer with the highest percentage up to 21.90, and then we often answer with $21.50 \%$, always $18.50 \%$, rarely $18.50 \%$ and $19.60 \%$ never. Based on this all the answers varies from a minimum of $18.50 \%$ to a maximum of 21.90 . Based on this, we can say that this has an impact factor usually followed with a sense of security to the overall percentage of $80.40 \%$ (in four scales: always, often, sometimes and rarely).

\section{Conclusions}

Statistical analysis of this research have shown detection of crimes and their perpetrators have a limited effect in reducing the crime rate without participation of other entities and social communities in preventing and combating crime.

Citizens express a distrust of institutions to social control and feel somehow increasingly insecure. Hereby, it is clear that adequate authorities may be proud of reducing crime statistics, however they can not affect the sense of security among the citizens. During this research we have confirmed our hypothesis. Main - Official statistics of crime in Gjilan, in quantitative terms are distinguished from the perception of crime by the citizens of this city gained from their research of victimology properties. Due to what we have realised in our research there are many factors that affect the criminal fear and sense of danger in Gjilan, which are quite complex and attached to many socio-demographic characteristics. However, previous victimization has not been discovered due to fear facing victimes for various reasons.

In this domain property protection measures in Gjilan show the following only 9.2 from $\mathrm{N}=270$ respondents have taken measures. Also, previous contacts with the police and judicial authorities are the key factors affecting the fear of crime and the sense of danger in Gjilan. Discovered offenses by police and meritory dilivery of sentences by the court would reduce to some extenssion fear of crime.

Importan role in reducing fear from criminality has been the role of neighbours and thei perception all along with personality features, etc.

Gjilan city neighborhoods where this research took place almost has the same problem based on an analyse carried out by the Police Statistics in Regional level in Gjilan.

What is interesting, several quarters compared with other quarters, is that those citizens who were victims of crime do not feel a high insecurity now and in principle they are satisfied with the police and have faith in their work.

This research reflects in detail the work to explore and understand the fear of crime and the sense of danger in Gjilan. Such work is very important because it affects in particular the measures needed by police, judiciary authorities, Municipal Assembly, various Directorates of the Municipality of Gjilan for the prevention of recidivism and crime in general. To enhance the trust of citizens, it is necessary commitment of the aforementioned authorities in order to lower the fear of crime.

In this regard, data and results presented in this research, which arose out of the analysis of our work can serve relevant institutions in designing appropriate policies to prevent and combat the negative phenomenon affecting the fear of crime. 
A good strategy for crime prevention not only prevents crime and victimization, but increases the safety of the community in the country, and promotes more security to all age groups affected by the fear of crime and simultaneously increases the confidence of the community in all organizations that fight crime.

\section{References}

Borooah, V.K., Carcach, C.A. (1997): Crime and fear: evidence from Australia. British Journal of Criminology, 37, 4, 635-657.

Chockalingam, K. i Srinivasan, M. (2009). Fear of crime victimization: A study of university students in India and Japan. International Review of Victimology, 16, 89-117.

Doležal, D. (2009). Razumijevanje straha od kriminaliteta. Hrvatska revija za rehabilitacijska istraživanja, 45, 1-14.

Doob, A. N. i Macdonald, G. E. (1979). Television viewing and fear of victimization: Is the relationship causal?. Journal of Personality and Social Psychology, 37, 170-179.

European Communities (2004) A review of scientifically evaluated good practices for reducing feelings of insecurity or fear of crime in EU member states. Pribavljeno 16.04.2010. s adrese http://www.eucpn.org.

Fattah, E. A., Sacco, V. F. (1989): Crime and victimization of the elderly. Springer-Verlag, New York.

Ferraro, K, LaGrange, R.L. (1987): The Measurement of Fear of Crime. Sociological Inquiry, 57, 70-101.

Gallup (2009). nga adresa http://www.gallup.com/home.aspx .

Garofalo, J. (1979): Victimization and fear of crime. Journal of Research in Crime and Delinquency, 16, 1, 80-97

Graber, D. (1980). Crime news and the public. New York: Praeger.

Gjoni, V. G. (2006) Strah od kriminaliteta: Obilježja spola i dobi. Hrvatski ljetopis za kazneno pravo i praksu, 13, 171-187.

Lane, J., Meeker, J.W. (2000): Subcultural divesity and the fear of crime: role of social and physical incivilities. Journal of Research in Crime and Delinquency, 29, 3, 311-334.

Ministry of internal affairs (2012). Kosovo Police, Annual Report.

Ministry of internal affairs (2013). Kosovo Police, Annual Report.

Ministry of internal affairs (2014). Kosovo Police, Annual Report.

Rountree, P.W., Land, K.C. (1996): Burglary victimization, perceptions of crime risk, and routine activities. Journal of Research in Crime and Delinquency, 33, 3, 147-179.

Skogan, W.G., Maxfield, M.G. (1981): Coping with Crime: Individual and Neighborhood

Tolle, E. (2001): Origin of Fear. www.healthy.net

Van der Wurff, A., Van Staalduinen, L., Stringer, P. (1989), Fear of Crime in Residential Environments: Testing a Social Psychological Model. Journal of Social Psychology, Vol.129, No.2: 141-60.

Warr, M. (2000). Fear of crime in the United States: Avenue for research and policy. In: D. Duffe, D. (Ed.), Measurement and Analysis of Crime and Justice (pp. 451-489). Washington: National Institute of Justice. 